\title{
Hatching and emergence success in green turtle Chelonia mydas nests in the Galápagos Islands
}

\author{
Patricia Zárate ${ }^{1,2, *}$, Karen A. Bjorndal ${ }^{1}$, Macarena Parra ${ }^{2}$, Peter H. Dutton ${ }^{3}$, \\ Jeffrey A. Seminoff ${ }^{3}$, Alan B. Bolten ${ }^{1}$
}

${ }^{1}$ Archie Carr Center for Sea Turtle Research and Department of Biology, University of Florida, Gainesville, Florida 32611, USA

${ }^{2}$ Marine Science Program, Charles Darwin Foundation, Santa Cruz Island, Galápagos Islands, Ecuador

${ }^{3}$ NOAA-National Marine Fisheries Service, Southwest Fisheries Science Center, La Jolla, California 92037, USA

\begin{abstract}
The interactions of numerous abiotic and biotic factors experienced by sea turtle embryos during incubation affect their survival. In this study we determined the hatching and emergence success of green turtles Chelonia mydas from nests on 4 beaches on the Galápagos Islands, one of the most important rookeries for green turtles in the eastern Pacific Ocean. Mean $( \pm \mathrm{SD})$ hatching and emergence success for the 1039 nests examined were $46.0 \pm 33.4$ and $45.6 \pm$ $33.4 \%$, respectively. These values are relatively low compared to other green turtle populations worldwide. We evaluated the effects of beach, year, day of oviposition, carapace length and width of female, nest position, nest habitat, and nest chamber depth on hatching and emergence success with binomial generalized additive models with fixed effects. We found variation in hatching and emergence success was significant among beaches, years, day of oviposition, and nest habitat. Predation by feral pigs and beetles and destruction of earlier nests by nesting females were the most important causes of embryo mortality. Efforts to keep threats at minimum levels, particularly controlling pigs near Isabela beaches, should be considered a major conservation objective. This study highlights important differences among beaches within a rookery and emphasizes the need to continue improving management strategies to protect green turtles and their critical habitats. Quantitative information provided here can be used as a basis for long-term studies in the Galápagos and for comparison to other sea turtles rookeries.
\end{abstract}

KEY WORDS: Chelonia mydas $\cdot$ Sea turtle reproduction $\cdot$ Clutch success $\cdot$ Generalized additive models $\cdot$ Pacific Ocean $\cdot$ Predation $\cdot$ Feral pigs $\cdot$ Beetles $\cdot$ Reptiles

Resale or republication not permitted without written consent of the publisher

\section{INTRODUCTION}

The importance of hatchling survivorship for longterm sea turtle conservation has been clearly demonstrated in a series of both empirical (Dutton et al. 2005, Marcovaldi \& Chaloupka 2007) and theoretical (Chaloupka 2002, Mazaris et al. 2006) studies. Hatchling survivorship is key for maintaining stable age structure and population size and essential for adult recruitment (National Research Council 2010).

Two metrics are used to measure survival during this life-history stage in sea turtles (Miller 1999). Hatching success is the proportion of eggs from which hatchlings emerge in the nest chamber. Emergence success is the proportion of eggs from which hatchlings emerge from the nest chamber and reach the surface of the beach. Usually emergence success is slightly lower than hatching success because not all hatchlings reach the beach surface.

Although hatching and emergence success are direct and simple measurements, surprisingly few data are available for nests left in situ (see Table S4 in the Supplement at www.int-res.com/articles/suppl/b019 p217_supp.pdf), given the hundreds of sea turtle nesting beaches that are monitored worldwide each year. Many studies of hatching and emergence suc- 
cess refer to artificial hatchery operations (Hirth 1997) or experimentally manipulated clutches of eggs (Ackerman 1980) that may not reflect natural survival rates (Wyneken et al. 1988, Abella et al. 2007).

Hatching and emergence success depends upon the interaction of numerous abiotic and biotic factors and varies among species and populations of sea turtles (Hirth 1980, Van Buskirk \& Crowder 1994). Temperature (Matsuzawa et al. 2002, Segura \& Cajade 2010), moisture (Ackerman 1980, Mortimer 1982), sand structure and composition (Mortimer 1990), and salinity (Ackerman 1980) can affect embryonic development by altering nest conditions. Hatching success can be affected by the nest location and its microhabitat or surrounding environment (Whitmore \& Dutton 1985, Bjorndal \& Bolten 1992, Hays \& Speakman 1993). Human activities on nesting beaches resulting in sand compaction can decrease hatching and emergence success (Kudo et al. 2003). Predation of sea turtle eggs and hatchlings by a wide taxonomic range of predators can have major effects; both native and introduced animals can substantially reduce hatching and emergence success (Stancyk 1982).

Clutches deposited earlier in the season can subsequently be destroyed by females digging egg chambers later in the season. The probability of this mortality source is highly dependent on nest density. As the density of nesting females increases, the probability of one female excavating another nest increases (Bustard \& Tognetti 1969, Tiwari et al. 2006, Honarvar et al. 2008).

In the eastern Pacific Ocean, green turtles Chelonia mydas have been heavily affected by human exploitation, and, globally, green turtles are considered 'Endangered' (IUCN 2012). The Galápagos Islands host one of the most important rookeries for green turtles in the eastern Pacific Ocean. The population appears to be stable, making up $>40 \%$ of the green turtles in the region (Seminoff 2004, 2007).

Green turtle nesting in the Galápagos coincides with the warm and rainy season from December to May, with peak nesting in February and March (Green \& OrtizCrespo 1982, Zárate \& Dutton 2002). Earlier studies on nest predation in Galápagos green turtles (Green \& Ortiz-Crespo 1982, Hurtado 1984) found that hatching and emergence success varied among beaches. Whereas mean hatching and emergence success of about 70 to $80 \%$ were found on beaches where no egg depredation or nest flooding occurred, low mean hatching and emergence values of about $40 \%$ were found on nesting beaches where nest depredation was caused by feral pigs and beetles. These studies were conducted decades ago; further investigation is needed because of the important contribution of the Galápagos to the regional green turtle population.

The aim of our study was to determine the hatching and emergence success of natural green turtle nests in the Galápagos and to evaluate the effects of beach, year, day of oviposition, size of female, nest position, nest habitat, chamber depth, and depredation impacts. Understanding the factors affecting hatching and emergence success and their impacts on different beaches is important for nesting beach management and will help to improve strategies for the protection and conservation of these critical habitats for green turtles in the Galápagos Archipelago. Our modeling approach can be applied to nesting beaches around the world.

\section{MATERIALS AND METHODS}

\section{Study site}

Our study was conducted on the 4 green turtle Chelonia mydas nesting beaches (Fig. 1) - Quinta Playa $\left(1.00^{\circ} \mathrm{S}, 91.08^{\circ} \mathrm{W}\right)$ and Bahía Barahona $\left(0.98^{\circ} \mathrm{S}\right.$,

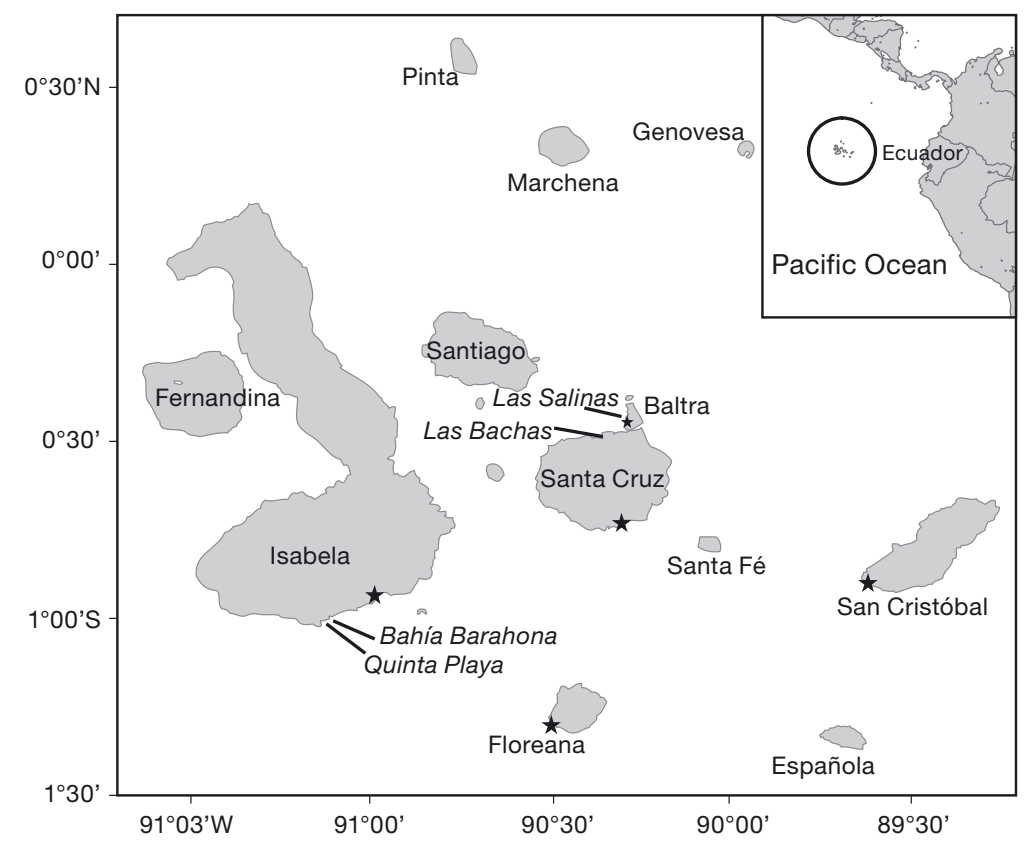

Fig. 1. Chelonia mydas. Map of the Galápagos Islands showing the green turtle nesting beaches used in this study. Stars represent island towns 
$\left.91.03^{\circ} \mathrm{W}\right)$ on Isabela Island, Las Bachas $\left(0.49^{\circ} \mathrm{S}\right.$, $90.33^{\circ} \mathrm{W}$ ) on Santa Cruz Island, and Las Salinas $\left(0.47^{\circ} \mathrm{S}, 90.29^{\circ} \mathrm{W}\right)$ on Baltra Island - that have the highest nesting activity in the Galápagos (Zárate \& Dutton 2002).

The 4 study beaches vary considerably in length, intertidal zone distance, beach slope, nesting zone width, beach area, and open access from the ocean (Table S1 in the Supplemen). The supralittoral vegetation area of Quinta Playa is a wide dense band mostly composed of buttonwood Conocarpus erectus and to a lesser extent of black mangroves Avicennia germinans. Dune (open beach) vegetation consists mostly of sea purslane Sesuvium portulacastrum, beach morning glory Ipomoea pescaprae, and saltworts Batis maritima. Bahía Barahona's supralittoral vegetation consists mainly of white Laguncularia racemosa and red Rhizophora mangle mangroves, buttonwoods, and, to a lesser extent, black mangroves. Dune vegetation is very similar to that at Quinta Playa. Las Bachas has greater plant diversity, including several endemic species. Supralittoral vegetation is composed of white and black mangroves and palo santo trees Bursera graveolens, desertthorn Lycium minimum, and shrubs of Maytenus octogona. Dune vegetation is mainly composed of saltbushes Cryptocarpus pyriformis, sea purslanes, and quail plants Heliotropium curassavicum. A few patches of desert-thorn, saltworts, and sea purslane can be found in the dune area of Las Salinas.

\section{Data collection}

Surveys were conducted every night throughout the nesting season on the 4 beaches during 4 consecutive nesting seasons from 2003/2004 through 2006/2007 (December to June). Hereafter, each nesting season will be referred to by using the second year in the sequence (e.g. the 2003/2004 season is referred to as 2004). Tags with an identification code and return address were attached to each nesting turtle on each front flipper (Style 681 Inconel tags, National Band \& Tag). Curved carapace length (CCL) from the nuchal notch to the tip of the longer supracaudal scute and curved carapace width (CCW) at the turtle's widest point were measured (Bolten 1999). Numbers of eggs with and without yolks (hereafter referred to as eggs and yolkless eggs, respectively) in each clutch were also recorded. Yolkless eggs are easily distinguished from yolked eggs by a much smaller size and nonspherical shape. Clutch size always refers to the number of yolked eggs. Eggs were counted using a hand tally counter as they fell from the females during oviposition without being handled. The eggs were left in situ to develop under natural conditions. All nests were marked by placing a wooden stick with coded tag in the sand about $10 \mathrm{~cm}$ in front of the edge of the clutch, and nest location was recorded by GPS and mapped along with reference points so the nests could be identified after emergence. Marked nests were checked daily for disturbance by predators, wave action, nesting activity by other turtles, and/or human activity. Causes of nest destruction or depredation as well as the number of nests and eggs affected were recorded.

Nest location was assigned based on the zone where the clutch was laid: (1) intertidal, (2) beach slope, (3) open beach (dune), or (4) supralittoral vegetation. The slope represents the natural inclination of the sand on the beach face, which is the zone of highest wave action. The supralittoral vegetation zone can either be a dense band of vegetation or small patches of vegetation behind the open beach.

Nest habitat was classified according to the immediate surrounding environment of each nest: (A) bare sand, (B) creeping vegetation, (C) small bushes, or (D) large bushes and trees. These nest environment categories were assigned independently of the zone in which the clutches were laid.

Egg chamber depth was measured with a steel measuring tape or meter stick from the bottom of the nest to the bottom of the body pit (a pit dug with the front flippers in which the turtle lies while digging the nest chamber). This measurement was taken by an observer lying on the sand behind the turtle just before oviposition. The distance from the nest to the beach high water mark (HWM) was measured by a $100 \mathrm{~m}$ measuring tape. Nest density was calculated as the number of nests divided by the beach area $\left(\mathrm{km}^{2}\right)$ and expressed as nests per $10 \mathrm{~m}^{2}$ by each beach and year.

Nests were excavated by hand 70 d after oviposition, thus allowing completion of the natural emergence process (mean incubation period $=55.0 \pm 4.9 \mathrm{~d}$; $\mathrm{n}=$ 160). Not all clutches deposited over the course of each nesting season were included in our study because of time constraints. Nests were sampled to ensure even spatial and temporal coverage. Unhatched eggs and hatchlings remaining in the nest chamber were counted. Unhatched eggs were opened to assess the extent of embryonic development according to the following characteristics adapted from Miller (1999): UD stands for no visible embryonic development (either early embryonic mortality or infertile); UH1, 
for embryos without pigmentation; UH2, for pigmented embryos; UH3, for full term embryos with a small amount of external yolk material; and ND, for embryos that could not be assigned to a developmental stage because of deterioration. All hatchlings found in the nest chamber were either dead or moribund, with a low probability of survival, and all were counted as dead. Hatching success was determined using the following formula: [(total eggs - unhatched eggs)/total eggs] $\times 100$. Emergence success was determined by the formula: [(total eggs - unhatched eggs - dead hatchlings)/total eggs] $\times 100$.

Stage of embryonic mortality was recorded unless egg contents were too decomposed. For predation events, if the predator could be identified either by its presence in the nest or by characteristic eggshell damage, the numbers of embryos and hatchlings killed by each type of predator were recorded. When $>1$ predator was found at the same time in a nest and the cause of mortality for each embryo could not be determined, only one was considered as the cause of mortality. Overlap was most common between beetle larvae and fly larvae, and predation was assigned to beetle larvae based on their greater mortality impact. Predators found in the egg chamber were identified to the species level; fly larvae were reared for identification. Fungi were not identified. Percentages of eggs and nests affected by each mortality factor were calculated by beach and year and also for all beaches in all years for general comparison to other studies.

\section{Statistical analyses}

To evaluate the extent to which various parameters affected hatching and emergence success, a binomial generalized additive model (GAM) with fixed effects was used. Parameters considered in the GAM were beach, year, day of oviposition, number of yolk- less eggs, CCL and CCW of females, nest position, nest habitat, chamber depth, and distance to the HWM. Analysis of deviance was used to compare models and select the best model; F-tests were used because of overdispersion. Nonindependence of data (successive clutches from some individual females) was not addressed in our model. GAM analyses were conducted with S-PLUS software (v. 8.2.0, TIBCO Spotfire Software). Results were considered significant at the 0.05 level.

Mean hatching and emergence success were calculated by beach and year. All data are reported as means $\pm \mathrm{SD}$.

\section{RESULTS}

Our study was based on 1039 nests of green turtles Chelonia mydas. Because clutch size was not correlated with hatching success $(\mathrm{df}=1038, F=1.60, \mathrm{p}=$ 0.2055 ) or emergence success ( $\mathrm{df}=1038, F=1.98, \mathrm{p}=$ 0.1598 ), we used GAMs with fixed effects that did not include clutch size as a parameter. In the first model, independent variables were beach, year, day of oviposition, number of yolkless eggs, CCL and CCW of females, nest location, nest habitat, chamber depth, and distance to the HWM ( $\mathrm{n}=621$ ). Chamber depth and distance to HWM were not significant, so a second model was run without those parameters and with an increased sample size ( $\mathrm{n}=1031$ ). Only the 4 parameters - beach, year, nest habitat, and day of oviposition - were significant; number of yolkless eggs, CCL and CCW of females, and nest position were not significant. We repeated the model dropping all nonsignificant parameters. Comparison of the 2 models with analysis of deviance revealed no significant difference $(\mathrm{df}=17.83$, deviance $=506, F=$ $0.973, \mathrm{p}=0.489$ ). Thus, the model with 4 parameters was the best fit, although the model only accounts for $13.3 \%$ of the variation in hatching success (Table 1).

Table 1. Chelonia mydas. Hatching success in Galápagos green turtles. Summary of binomial general additive regression analysis with fixed effects (4-parameter model; logit link, cubic smoothing splines); $(F)$ is reported for the analysis of deviance test. A significant nonparametric $F$ means that the covariate is nonlinear; this test is only relevant for significant continuous model covariates $[\mathrm{p}(F)] \cdot \mathrm{R}^{2}=$ (null deviance - residual deviance) $/$ null deviance $=0.133$

\begin{tabular}{|lccccccc|}
\hline Parameter & df & Deviance & $\begin{array}{c}\text { Residual } \\
\text { df }\end{array}$ & $\begin{array}{c}\text { Residual } \\
\text { deviance }\end{array}$ & $\mathrm{p}(F)$ & $\begin{array}{c}\text { Nonlinear effects (nonparametric) } \\
\mathrm{df}\end{array}$ \\
Null & & & 1030 & 40659 & & \\
Beach & 3.00 & 3299 & 1027 & 37360 & $<0.0001$ & \\
Year & 3.00 & 1396 & 1024 & 35964 & $<0.0001$ & & \\
Nest habitat & 3.00 & 323 & 1021 & 35640 & 0.0114 & & 22525 \\
Day of oviposition & 4.00 & 373 & 1017 & 35267 & 0.0124 & 3 & $<0.0001$ \\
\hline
\end{tabular}


Table 2. Chelonia mydas. Mean hatching and emergence success of green turtles from nests by year and beach at 4 nesting beaches from 2004 through 2007. Beaches and years in bold represent lower hatching and emergence success values relative to other beaches and years, respectively. BB: Bahía Barahona; QP: Quinta Playa; LB: Las Bachas; LS: Las Salinas

\begin{tabular}{|c|c|c|c|c|c|c|c|c|}
\hline \multirow[t]{2}{*}{ Beach } & \multirow[t]{2}{*}{ Year } & \multirow{2}{*}{$\begin{array}{l}\text { Total no. } \\
\text { of nests }\end{array}$} & \multirow{2}{*}{$\begin{array}{l}\text { Nest density } \\
\left(\text { nests } 10 \mathrm{~m}^{-2} \text { ) }\right.\end{array}$} & \multirow{2}{*}{$\begin{array}{c}\text { Total no. } \\
\text { of eggs }\end{array}$} & \multicolumn{2}{|c|}{ Hatching success (\%) } & \multicolumn{2}{|c|}{ Emergence success (\%) } \\
\hline & & & & & Mean & $\mathrm{SD}$ & Mean & $\mathrm{SD}$ \\
\hline BB & 2004 & 88 & 0.7 & 6566 & 48.8 & 29.8 & 48.8 & 29.8 \\
\hline BB & 2005 & 127 & 0.3 & 8901 & 44.5 & 27.7 & 44.1 & 27.8 \\
\hline BB & 2006 & 130 & 1.4 & 9133 & 32.8 & 31.8 & 32.8 & 31.8 \\
\hline QP & 2004 & 78 & 1.0 & 5889 & 47.4 & 36.5 & 47.4 & 36.5 \\
\hline QP & 2005 & 139 & 0.5 & 9713 & 46.3 & 30.3 & 45.7 & 30.3 \\
\hline QP & 2006 & 121 & 1.4 & 8602 & 30.1 & 32.0 & 29.6 & 31.9 \\
\hline QP & 2007 & 165 & 1.6 & 11433 & 42.8 & 35.2 & 42.2 & 35.2 \\
\hline LB & 2004 & 55 & 0.2 & 4108 & 62.7 & 27.6 & 62.4 & 27.6 \\
\hline LB & 2005 & 47 & 0.1 & 3212 & 61.9 & 29.0 & 61.1 & 29.5 \\
\hline LS & 2004 & 40 & 0.2 & 2775 & 83.6 & 19.4 & 83.4 & 19.4 \\
\hline LS & 2005 & 49 & 0.1 & 3594 & 61.7 & 31.7 & 61.1 & 31.8 \\
\hline $\begin{array}{l}\text { All } \\
\text { beaches }\end{array}$ & $\begin{array}{c}\text { All } \\
\text { years }\end{array}$ & 1039 & 0.7 & 73926 & 46.0 & 33.4 & 45.6 & 33.4 \\
\hline
\end{tabular}

Mean values and ranges for all variables measured for the nesting females and nests are presented in Table S2 in the Supplement.

Variation in hatching and emergence success was significant among years and beaches (Table 2), so data could not be combined for analyses. Hatching success at Las Bachas and Las Salinas was significantly higher than that at Isabela beaches, and significantly lower hatching success was found in 2006 compared to 2004 and 2005 (Table 2, Fig. 2a,b). Nests covered by large bushes and trees (D in Fig. 2c) had significantly higher hatching success than clutches laid in bare sand (A in Fig. 2c). Day of oviposition had a significant nonlinear effect; clutches deposited early in the season had significantly lower hatching success (Table 1, Fig. 2d). Although it appears that hatching success declined at the end of the season, the wide confidence limits indicate that the decline is not significant.

Overall mean hatching and emergence success for the 1039 nests was $46.0 \%( \pm 33.4)$ and $45.6 \%( \pm 33.4)$, respectively. Hatching success was significantly lower for beaches where nest density was higher (Bahía Barahona and Quinta Playa) and significantly higher for beaches with low nest density (Las Bachas and Las Salinas; Table 2).

Emergence success is very similar to hatching success in Galápagos green turtle nests (Table 2, $\mathrm{R}^{2}=$ 0.99; Fig. S1 in the Supplement) with the exception of 5 nests. Dead hatchlings (6 to 60 hatchlings) were found in those nests, primarily from predation by fly larvae $(73.8 \%)$ and unknown causes $(26.2 \%)$. Because the model results for emergence success are almost identical to those of hatching success, only model results for hatching success are presented in this paper.

Embryo mortality was due to many factors including predation, nest destruction by other nesting females, tidal inundation (erosion and submergence), and invasion by plant roots. We observed predation by the native scarabeid beetle Omorgus suberosus, the feral pig Sus scrofa, native ghost crab Ocypode gaudichaudii, and fly larva species either introduced (Oxisarcodexia bakeri, Peckia chrysostoma, Sarcodexia lambens), or endemic (Galopagomyia inoa) (Tables $3 \& 4$ ). In some cases the entire clutch was destroyed, whereas in others only some of the embryos were killed.

Beetles affected 688 nests $(66.2 \%)$ and killed 23361 embryos (31.6\%; Tables 3 \& 4). Adult beetles burrow down to the egg chamber where they reproduce. Both larvae and adults feed on the egg contents after chewing through the shell. In most cases, it was impossible to determine the stage of embryonic mortality from beetles because of decomposition. Beetles attacked very few live or dead hatchlings $(\mathrm{n}<10)$. Mortality from beetles varied substantially among beaches. Beetles appear to have killed higher percentages of embryos in Bahía Barahona and Quinta Playa (27 to $44 \%$ ) than in Las Bachas and Las Salinas ( 0.8 to $22 \%$ ) (Tables $3 \& 4$ ). Beetle depredation was recorded throughout the season (Fig. 3a) and in all nest habitats.

Feral pigs destroyed 77 nests $(7.4 \%)$ and killed 5471 embryos ( $7.4 \%$; Tables 3 \& 4). Mortality from pigs varied greatly by island (pigs do not occur on Las Bachas or Las Salinas) and by year. Feral pigs were observed digging out nests with freshly laid 

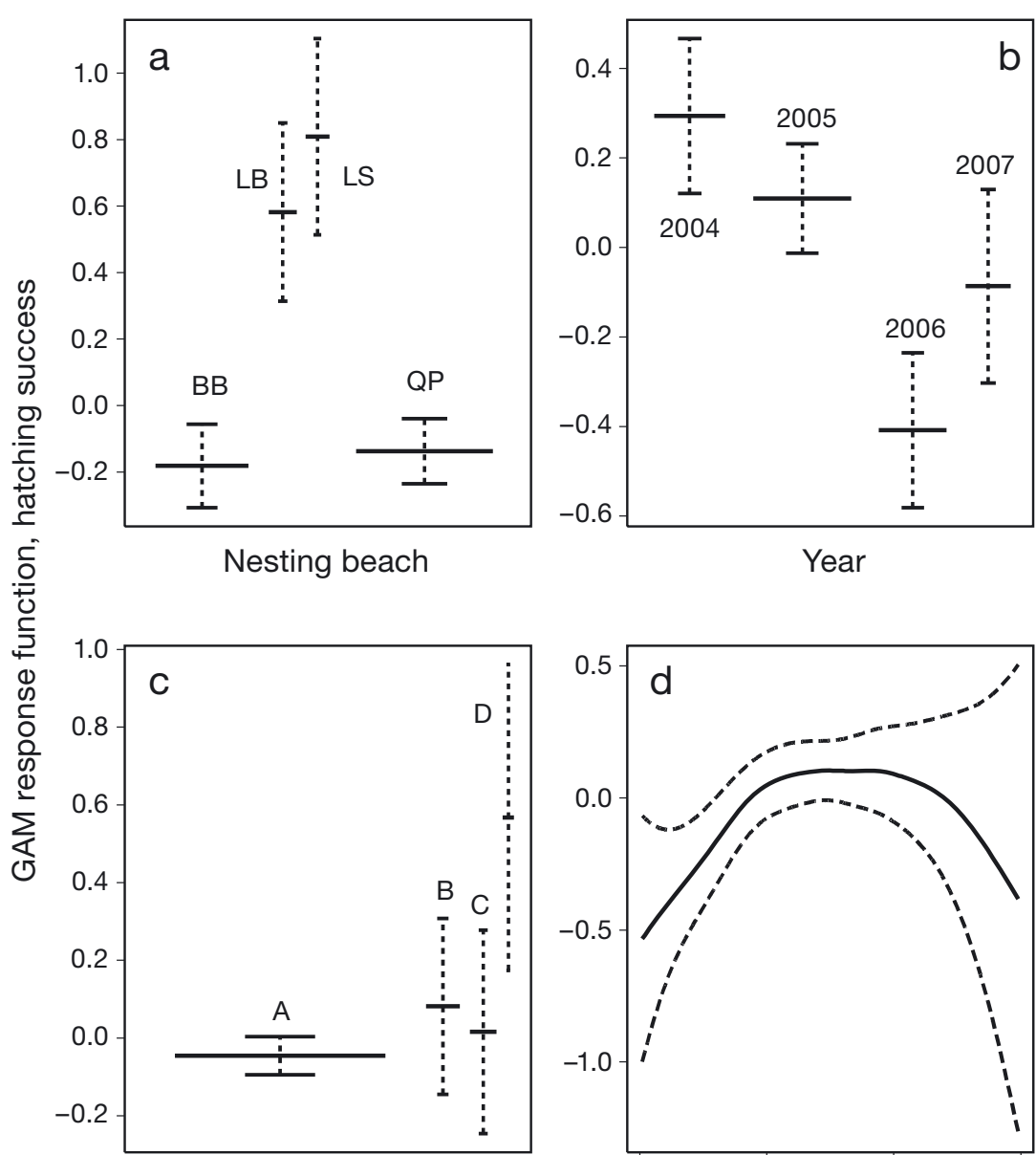

Nest habitat

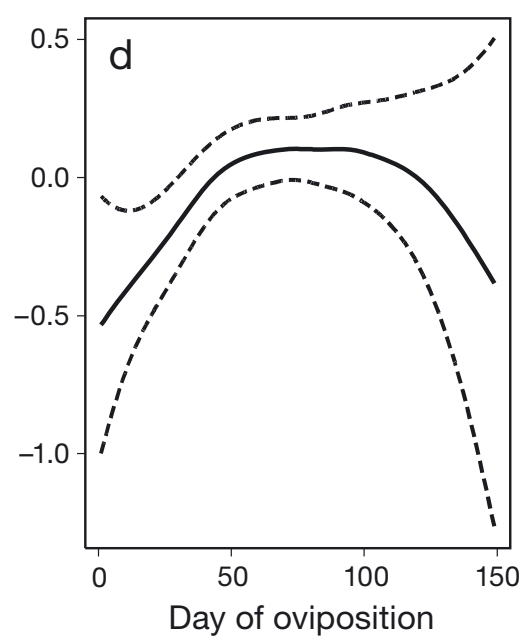

Fig. 2. Chelonia mydas. Graphical summary of GAM analysis of the 4 significant hatching success covariates in Table 1: (a) nesting beach, (b) year, (c) nest habitat, and (d) day of oviposition. All are significant. The response variable (hatching success) is shown on the $y$-axis as a centered smoothed function scale to ensure valid pointwise $95 \%$ confidence bands. The covariate is shown on the $x$-axis. For Panels $a, b$, and $c$, width of the mean covariate response is proportional to sample size with the $95 \%$ confidence interval shown by cross bars. In Panel d, the solid curve is the cubic smoothing spline fits for day of oviposition conditional on all other covariates in the GAM model. Dashed curves are pointwise $95 \%$ confidence curves around the fits. BB: Bahía Barahona; QP: Quinta Playa; LB: Las Bachas; LS: Las Salinas; for nest habitat, A: bare sand; B: creeping vegetation; C: small bushes; D: large bushes and trees. For day of oviposition, Day 1 is 15 December and Day 150 is 13 May

Ghost crabs, although abundant in the study beaches, affected only 56 nests $(5.4 \%)$ and killed 591 embryos $(0.8 \%$; Tables $3 \& 4)$. Crab burrows were often found around green turtle nests, and occasionally crabs were found in the egg chamber during excavation. Predation by crabs was identified by distinctive cuts in the eggshell. Predation of sea turtle embryos by ghost crabs occurred on all beaches except Las Salinas and was more common in clutches laid in areas of bare sand or creeping vegetation.

Fly larvae were found in eggs in 23 nests $(2.2 \%)$ and killed 148 embryos $(0.2 \%$; Tables $3 \& 4)$; they mainly fed on hatchlings in the nest, either alive or dead. Adult flies were observed on the surface of the beach over turtle clutches depositing larvae in the sand, which then burrowed down to the egg chamber. Larvae enter hatchlings through the yolk sac, cloaca, mouth, and eyes and consume internal organs and muscles. Fly larvae found in nests on Las Bachas and Las Salinas belonged to the Sarcophagidae family and included 3 introduced species (Oxisarcodexia bakeri, Peckia chrysostoma, and Sarcodexia lambens) and 1 endemic species (Galopagomyia inoa). The impact of each species on turtle eggs was not determined because fly larvae could not be identified in the field. Depredation by flies was observed at all beaches except Bahía Barahona.

Nesting female green turtles destroyed 28 nests $(2.7 \%)$ and killed 1996 embryos $(2.7 \%$; Tables

eggs or with pre-emergent hatchlings (hatchlings not yet emerged from the nest) and feeding on hatchlings moving to the sea. However, no information regarding stage of development of the embryos on nests destroyed by pigs was collected. Pigs preyed upon nests in all habitats except under large bushes and trees, and their impact appears to have been greater on clutches deposited early and late in the season (Fig. 3b).
3 \& 4). Nest destruction by nesting females was only recorded on Isabela beaches and had the greatest effect in 2006. Nest destruction by turtles was observed in all habitats except under large bushes and trees and had a greater effect on clutches deposited early in the season (Fig. 3c).

Wave action and flooding only destroyed 17 nests $(1.6 \%)$ and killed 1183 embryos (1.6\%; Tables 3 \& 4). All embryos from these nests were washed away or 
Table 3. Chelonia mydas. Percentages of nests affected by each source of mortality, and percentages of successful nests by beach and season for the Galápagos Islands. A successful nest is a nest that produced at least 1 hatchling that emerged on the surface of the beach. BB: Bahía Barahona; QP: Quinta Playa; LB: Las Bachas; LS: Las Salinas

\begin{tabular}{|c|c|c|c|c|c|c|c|c|c|c|c|}
\hline Beach & Year & $\begin{array}{l}\text { Total no. } \\
\text { of nests }\end{array}$ & Beetles & $\begin{array}{c}\text { Feral } \\
\text { pigs }\end{array}$ & $\begin{array}{l}\text { Nesting } \\
\text { females }\end{array}$ & Crabs & Flies & $\begin{array}{l}\text { Wave action/ } \\
\text { flooding }\end{array}$ & $\begin{array}{l}\text { Plant } \\
\text { roots }\end{array}$ & $\begin{array}{c}\text { Unknown } \\
\text { mortality sources }\end{array}$ & $\begin{array}{l}\text { Successful } \\
\text { nests }\end{array}$ \\
\hline $\mathrm{BB}$ & 2004 & 88 & 85.2 & 1.1 & 3.4 & 1.1 & 0 & 0 & 0 & 36.4 & 94.3 \\
\hline BB & 2005 & 127 & 87.4 & 0 & 2.4 & 0 & 0 & 0.8 & 1.6 & 56.7 & 97.6 \\
\hline BB & 2006 & 130 & 66.9 & 20.8 & 6.9 & 0.8 & 0 & 0 & 0 & 46.2 & 67.7 \\
\hline QP & 2004 & 78 & 64.1 & 16.7 & 1.3 & 0 & 0 & 0 & 0 & 33.3 & 80.8 \\
\hline QP & 2005 & 139 & 77.0 & 5.0 & 3.6 & 0.7 & 2.2 & 0.7 & 0 & 53.2 & 87.1 \\
\hline QP & 2006 & 121 & 54.5 & 24.0 & 5.8 & 1.7 & 0.8 & 1.7 & 0 & 57.9 & 66.1 \\
\hline QP & 2007 & 165 & 70.9 & 0 & 0 & 27.9 & 2.4 & 3.6 & 0.6 & 55.8 & 93.9 \\
\hline LB & 2004 & 55 & 81.8 & 0 & 0 & 9.1 & 3.6 & 0 & 0 & 89.1 & 96.4 \\
\hline LB & 2005 & 47 & 48.9 & 0 & 0 & 0 & 6.4 & 2.1 & 0 & 87.2 & 91.5 \\
\hline LS & 2004 & 40 & 0 & 0 & 0 & 0 & 15.0 & 0 & 0 & 90.0 & 100.0 \\
\hline LS & 2005 & 49 & 14.3 & 0 & 0 & 0 & 8.2 & 12.2 & 4.1 & 81.6 & 87.8 \\
\hline $\begin{array}{l}\text { All } \\
\text { beaches }\end{array}$ & $\begin{array}{c}\text { All } \\
\text { years }\end{array}$ & 1039 & 66.2 & 7.4 & 2.7 & 5.4 & 2.2 & 1.6 & 0.5 & 57.0 & 85.9 \\
\hline
\end{tabular}

Table 4. Chelonia mydas. Percentages of embryos in each nest assigned to each source of mortality by beach and year for the Galápagos Islands. Standard deviations are in parentheses. BB: Bahía Barahona; QP: Quinta Playa; LB: Las Bachas; LS: Las Salinas

\begin{tabular}{|lcccccccccc|}
\hline Beach & Year & $\begin{array}{c}\text { Total no. } \\
\text { of eggs }\end{array}$ & Beetles & $\begin{array}{c}\text { Feral } \\
\text { pigs }\end{array}$ & $\begin{array}{c}\text { Nesting } \\
\text { females }\end{array}$ & Crabs & Flies & $\begin{array}{c}\text { Wave action/ } \\
\text { flooding }\end{array}$ & $\begin{array}{c}\text { Plant } \\
\text { roots }\end{array}$ & $\begin{array}{c}\text { Unknown } \\
\text { mortality sources }\end{array}$ \\
\hline BB & 2004 & 6566 & $40.7(26.9)$ & $1.2(10.7)$ & $3.4(18.3)$ & $0.3(3.1)$ & 0 & 0 & 0 & $5.6(13.1)$ \\
BB & 2005 & 8901 & $44.2(28.6)$ & 0 & $2.7(15.2)$ & 0 & 0 & $0.8(8.9)$ & $0.4(2.1)$ & $7.4(18.0)$ \\
BB & 2006 & 9133 & $31.8(32.2)$ & $20.8(40.7)$ & $6.9(25.5)$ & $0.8(8.8)$ & 0 & 0 & 0 & $6.9(13.8)$ \\
QP & 2004 & 5889 & $31.3(33.1)$ & $16.7(37.5)$ & $1.3(11.3)$ & 0 & 0 & 0 & 0 & $3.3(8.0)$ \\
QP & 2005 & 9713 & $36.3(29.6)$ & $5.0(21.9)$ & $3.7(18.7)$ & $0.4(3.0)$ & 0 & $0.8(8.5)$ & 0 & $7.5(18.2)$ \\
QP & 2006 & 8602 & $27.2(34.0)$ & $24.0(42.9)$ & $5.8(23.4)$ & $0.9(9.0)$ & 0 & $1.7(12.8)$ & 0 & $10.3(20.1)$ \\
QP & 2007 & 11433 & $44.4(34.7)$ & 0 & 0 & $2.9(6.8)$ & 0 & $3.7(18.8)$ & $0.01(0.2)$ & $7.3(15.1)$ \\
LB & 2004 & 4108 & $22.5(21.9)$ & 0 & 0 & $1.1(5.9)$ & $0.4(1.7)$ & 0 & 0 & $14.4(20.5)$ \\
LB & 2005 & 3213 & $9.1(14.9)$ & 0 & 0 & 0 & $0.6(1.7)$ & $2.5(14.6)$ & 0 & $25.9(26.0)$ \\
LS & 2004 & 2775 & 0 & 0 & 0 & 0 & $0.7(2.3)$ & 0 & 0 & $15.7(18.0)$ \\
LS & 2005 & 3594 & $0.8(2.9)$ & 0 & 0 & 0 & $0.5(2.3)$ & $12.2(33.1)$ & $1.1(5.6)$ & $23.7(22.9)$ \\
All & All & 73926 & $31.6(32.1)$ & $7.4(26.2)$ & $2.7(16.2)$ & $0.8(5.6)$ & $0.2(2.6)$ & $1.6(12.7)$ & $0.1(1.4)$ & $9.6(18.1)$ \\
beaches & years & & & & & & & & &
\end{tabular}

appear to have drowned in the nest. Impact was greater on nests in Las Salinas and Quinta Playa. Of these nests, $76 \%$ were destroyed in the second half of the nesting season. No information regarding stage of development of the embryos in these nests was collected.

Plant roots invaded only 5 nests $(0.5 \%)$ and killed 74 embryos $(0.1 \%$; Tables $3 \& 4)$, the lowest values among the known causes of mortality. Three of these nests $(60 \%)$ were located in areas with creeping vegetation and small bushes. Root invasion was recorded only in 2005 at Bahía Barahona and Las Salinas and only in 2007 at Quinta Playa.
A total of 7097 embryos (9.6\%) in 592 nests (57\%) (Tables 3 \& 4) died from undetermined causes at all beaches, but mostly at Las Bachas and Las Salinas. Unknown causes of embryonic failure were observed in all nest habitats and throughout the season.

Fungi infested 744 nests $(71.6 \%)$ and 21069 $(29.7 \%)$ of the eggs (Table S3 in the Supplement). We could not determine whether fungus was a source of mortality, but it was present in $>50 \%$ of nests at each beach and year (Table S3). Nest infestation was recorded in all nest habitats and throughout the season. 

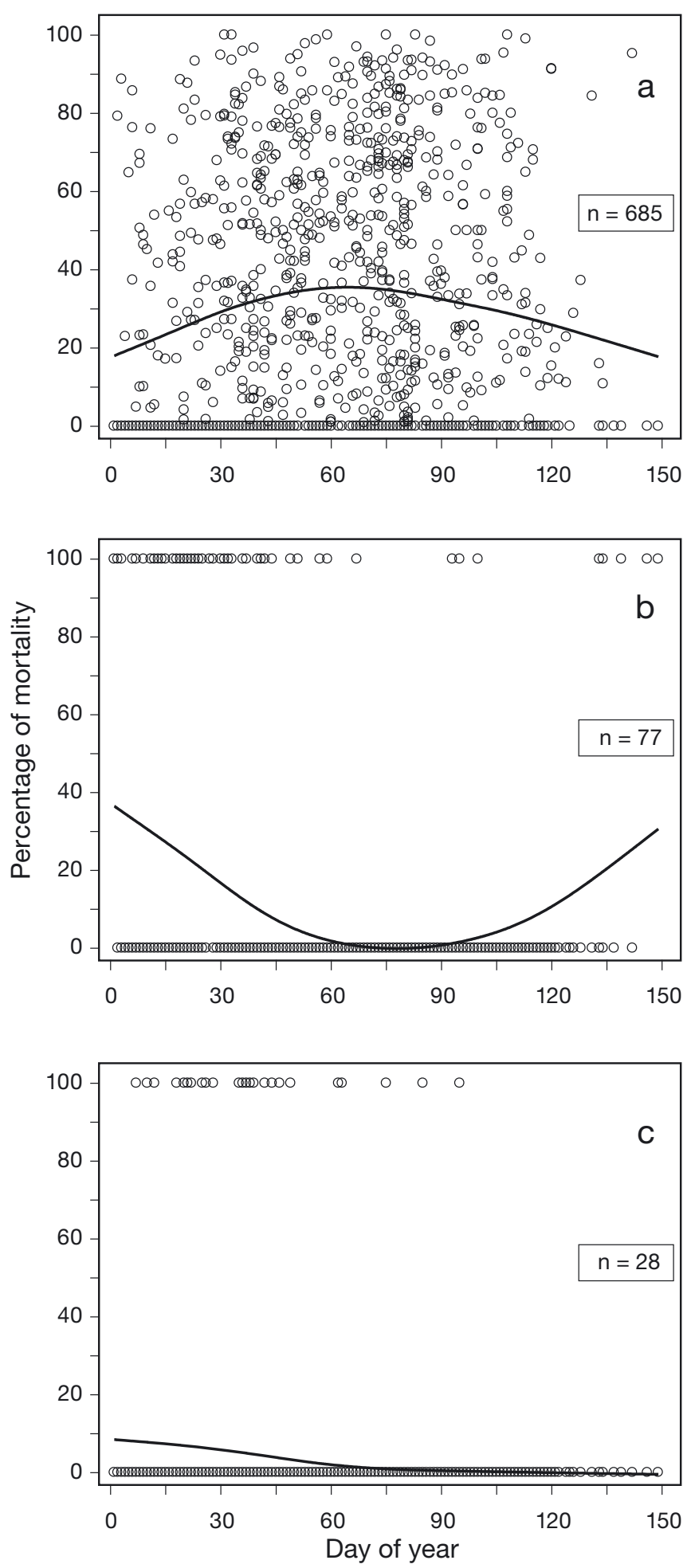

Fig. 3. Chelonia mydas. The relation of day of oviposition and percentage of embryos killed in individual nests $(\mathrm{n}=$ 1039) by the 3 mortality factors that changed across the season: (a) beetles, (b) feral pigs and (c) nesting females. N-values are the numbers of nests affected by each factor; circles are values for each nest; lines are cubic smoothing splines with $\mathrm{df}=4$. Day 1 is 15 December and Day 150 is 13 May

\section{DISCUSSION}

\section{Variation in hatching success and comparisons with other sea turtle populations}

The mean hatching success and emergence success values found in this study were relatively low compared to other green turtle populations where most values have been shown to be $>70 \%$ (Table S4 in the Supplement). Low hatching success at other beaches is usually associated with intensive predation pressure (Brown \& Macdonald 1995, Turkozan et al. 2011) or very poorly sorted substrates (Mortimer 1990). The lowest hatching and emergence success for green turtles were recorded at Espumilla Beach on Santiago Island, Galápagos. This beach was severely infested by feral pigs, resulting in a hatching success of $1.8 \%$ (Green \& Ortiz-Crespo 1982). Pigs have since been eradicated on Santiago Island (Cruz et al. 2005).

Lower hatching and emergence success values were recorded on Quinta Playa and Bahía Barahona than on Las Bachas and Las Salinas. Three characteristics of Bahía Barahona and Quinta Playa had strong influences on the lower hatching and emergence success on those beaches: the presence of beetles and pigs and higher turtle nest density. Compared to earlier years (Green \& Ortiz-Crespo 1982, Hurtado 1984), our values for hatching and emergence success at Quinta Playa and at Las Salinas were similar, but for Bahía Barahona and Las Bachas we obtained lower values (Table S4 in the Supplement).

The beetle Omorgus suberosus, which was the major known source of mortality for embryos in our study, has been reported to prey on green turtle eggs on Quinta Playa, Bahía Barahona, and La Picona (Floreana Island) (Allgoewer 1980, Green \& Ortiz-Crespo 1982, Hurtado 1984). In our study, beetle predation in Quinta Playa was similar to that in earlier studies $(\sim 30 \%)$, but beetles killed twice the number of embryos in Bahía Barahona compared to earlier data (18.9\%; Allgoewer 1980). Differences among years probably result from variation in beetle abundance or rainfall. A relation among turtle nest density, beetle density per nest, and destruction rate has been established (Allgoewer 1980, Halffter et al. 2009). The beetles reproduce only in wet weather (López et al. 1994), so the low levels of beetle depredation during 2006 in Quinta Playa and Bahía Barahona might be explained by low rainfall during that year (Charles Darwin Foundation 2012). Prior to our study, beetles had not been reported in green turtle nests on Las Salinas 
and Las Bachas. The low impact of beetles on green turtle hatching and emergence success on these 2 nesting beaches could be due to the low turtle nest density on these beaches.

The only other record of depredation by the beetle Omorgus suberosus on sea turtle eggs is at La Escobilla beach, Oaxaca, Mexico, where the beetles infest olive ridley Lepidochelys olivacea nests (Ocana 2011) and are the major cause for nest failure and low hatching success. Our results are very similar to those from La Escobilla, where most nests show evidence of beetle depredation (Ocana 2011), but all eggs in the nest are not always affected.

Pigs are commonly found on Isabela Island, but depredation by pigs on Isabela beaches was restricted to specific periods in some years. Although feral pigs are primarily herbivores, they feed opportunistically on a wide range of food items including sea turtle eggs and hatchlings (Coblentz \& Baber 1987, Cruz et al. 2005). Pigs are generally restricted to highelevation habitats in the Galápagos, where abundant and succulent forage is available most of the year (Coblentz \& Baber 1987). However, in dry years, feral pigs move down from highland to coastal areas in search of food (Calvopiña 1985). The increase in predation by pigs observed in 2006 on Isabela beaches coincides with the low levels of precipitation during that year (Charles Darwin Foundation 2012). Pigs are a major cause of leatherback egg mortality in Papua, Indonesia (Hitipeuw et al. 2007, Tapilatu \& Tiwari 2007) where percentages of nest destruction by pigs vary from 5 to $40 \%$ of total nests in a season (Starbird \& Suarez 1994). Lower destruction percentages in our study possibly result from smaller pig populations due to long-term management actions in the Galápagos.

Pig depredation is most common at the beginning and end of the season and tracks the within-season day-of-oviposition pattern revealed by the GAM analyses. Visual and olfactory cues used by feral pigs for prey detection (Hayes et al. 1996) are more effective when nest density is low. Because digging is energetically costly, pigs will dig out nests when there is a higher chance of success (Leighton et al. 2009). Other mammalian predators such as dogs in Tortuguero, Costa Rica, follow a similar pattern with increasing predation at the end of the season when nest density is low (Tiwari et al. 2006).

Nest destruction by nesting females on Isabela beaches varied among years and across seasons. This type of nest destruction is a density-dependent source of mortality (Bustard \& Tognetti 1969, Cornelius et al. 1991, Tiwari et al. 2006, Honarvar et al.
2008). With an increase in the number of nesting females, the probability of a female destroying an earlier nest while digging her own nest chamber increases. The higher nest density observed during 2006 in Quinta Playa and Bahía Barahona resulted in an increase in the proportion of nests destroyed by turtles digging nest chambers, suggesting densitydependent effects. The lower hatching and emergence success for clutches laid earlier in the season may be a result of most early nesting occurring on beaches with higher nesting activity such as in Quinta Playa and Bahía Barahona. Nesting begins in early December on Bahía Barahona and Quinta Playa, and about a month later on Las Bachas and Las Salinas. Early nests are more vulnerable to subsequent destruction from other nesting turtles.

Nest destruction by later nesting sea turtles has been observed in high nest density populations such as in green turtles from Tortuguero, Costa Rica (Tiwari et al. 2006), and the southern Great Barrier Reef, Australia (Bustard \& Tognetti 1969, Limpus et al. 2003), in leatherbacks from French Guiana (Girondot et al. 2002), and olive ridleys in Costa Rica (Honarvar et al. 2008). Nest destruction rate from nesting females in Tortuguero, Costa Rica, is 4 times higher (Tiwari et al. 2006) than our estimates from Bahía Barahona and Quinta Playa, which probably reflects differences in population density.

In our study, the habitat directly around the nest did not have an effect except for clutches laid under large bushes and trees that had higher hatching and emergence success than those in other habitats. Most of these nests (95\%) were found on Bahía Barahona and Quinta Playa where pigs and nesting females are major causes of mortality. However, mammal depredation and nesting females were never recorded as a source of mortality in this nest habitat, which could explain the higher hatching and emergence success. Most nests found under large bushes and trees were located in the open beach zone where shade may lessen loss of moisture and buffer temperatures (Foley et al. 2006). At other nesting beaches, low hatching success in nests located in vegetated areas may result from higher rates of predation by forestdwelling predators (Bjorndal \& Bolten 1992, Caut et al. 2006).

\section{Unknown sources of mortality}

Only $13.3 \%$ of the variation in hatching success was explained by GAM analysis. The proportion would undoubtedly have been higher if we had been 
able to quantify more variables for each beach in each year, such as pig and beetle abundance, changes in nest density throughout the seasons, rainfall, and physical parameters of the beach substrate.

Physical parameters of the beach substrate, such as gas exchange, sand moisture, and temperature are important factors for the survival of sea turtle embryos and can affect hatching and emergence success (Mrosovsky \& Yntema 1980, Mortimer 1990). Seasonal changes in sand temperature resulting in temperatures outside of the viable range can induce seasonal changes in mortality. Embryos die from hyperthermia in nests with temperatures $>33^{\circ} \mathrm{C}$ for an extended period of time (Matsuzawa et al. 2002). High nest temperatures can reduce emergence success by limiting the ability of hatchlings to reach the surface (Matsuzawa et al. 2002). Amount of rainfall affects hatching success of green turtles at Raine Island, Australia, where drier years have lower rates of hatching and nesting success (Limpus et al. 2003).

Another important aspect of temperature that deserves attention in the Galápagos is the effect on the sex ratios of sea turtle hatchlings, with potentially wider implications for the survival of the population. Katselidis et al. (2012), studying long-term variation of hatchling sex ratios from loggerhead turtle nests at Zakynthos, Greece, showed that males and females were produced at different times within a season and that some beaches were responsible for male production, while females were produced on other beaches. Understanding the range of male versus female offspring production within a rookery may be critical for specific management actions at each nesting beach. Global climate change may shift hatchling production on tropical beaches to a single sex (Witt et al. 2010).

The role of fungi in sea turtle nests is poorly understood and deserves greater attention. Fungus infestation has been described in all sea turtle species around the world in eggshells, embryonic tissues, and sand surrounding nests (Peters et al. 1994, Phillott \& Parmenter 2001, Güçlü et al. 2010). However, the actual effect of fungus on embryonic mortality is difficult to establish. The infestation and dispersion of the fungi throughout a clutch is thought to be opportunistic; an egg that is already decaying will be invaded by soil mycobiota (Phillott \& Parmenter 2001). Güçlü et al. (2010) found that hatching success in loggerhead nests in Turkey was negatively correlated with the total number of isolated fungi genera. In our study, fungi were present in $>70 \%$ of nests, but we could not determine whether it was a source of mortality.

\section{Management actions and recommendations}

Important management questions are whether the current management plan will succeed in protecting green turtles at key nesting beaches in the Galápagos and what specific conservation actions should be undertaken based on the threats identified here. We have confirmed that beetles and feral pigs are major threats to turtle nests at Bahía Barahona and Quinta Playa. We have also identified destruction of nests by nesting females as a new important threat to Isabela beaches.

The Galápagos Archipelago has the greatest level of vertebrate endemism among all islands in the eastern Pacific Ocean (Plan de Manejo del Parque Nacional Galápagos 2005). Control and management strategies such as eradication or elimination of invasive species have been established by the Galápagos National Park Service (GNPS) to protect endemic and native species. The eradication of pigs on Santiago Island after an intensive and expensive campaign was a major victory (Cruz et al. 2005). Since then, the number of green turtle nests on that island has increased (Zárate 2003). A feral pig eradication program that includes the Isabela beaches has been underway since the 1980s. This program keeps pig populations at low levels and should be maintained as a high priority.

With the exception of feral pigs, major factors influencing hatching and emergence success in the Galápagos Islands are of natural origin. Thus, the elimination of the native scarabeid Omorgus suberosus from green turtle beaches is not an option. Predation by beetles deserves attention, particularly at Isabela beaches where hatching and emergence values are already very low. Our new records of this beetle in Las Salinas and Las Bachas are of great concern and could represent a serious risk for green turtles on these beaches in the future. Beetle reproduction is influenced by climatic conditions and changes in weather associated with El Niño events; climate change could also increase the impact of $O$. suberosus on green turtle nests. Further research on this species is encouraged to better understand the ecological role of beetle predation, the factors that determine which turtle nests are infested, and whether human activities transport beetles among beaches.

No direct threats from human activities such as pedestrian traffic, egg poaching, or turtle capture were recorded during our study, but they do occur to some extent. Isabela beaches and Las Salinas frequently have unauthorized visitors who use the beach as a recreational site. Las Salinas and Las 
Bachas are located in the vicinity of a major tourist center formed by the main airport and port on Baltra Island and the Itabaca Canal. Thus, concern exists about the increased tourism activity at Las Bachas during the past decade.

Conservation measures implemented solely on nesting beaches may not be effective when in-water threats are present. The categories currently assigned to our study beaches under the Galápagos Marine Reserve allow different activities at sea and along the coast of the islands that affect sea turtles. As a consequence, major threats to sea turtles in Galápagos waters are boat strikes, fishing interactions, and direct capture. All of these aspects are of great concern but are difficult to resolve in the short term. The process of management of the Galápagos Marine Reserve requires the participation of all stakeholders at the Participatory Management Board (Plan de Manejo de Conservación y Uso Sustentable para la Reserva Marina de Galápagos 1999). These increasing threats at sea reinforce the need to give high conservation priority to keeping the impacts on nesting beaches at minimum levels, particularly on Isabela beaches, which have the highest level of green turtle nesting activity in the islands (Hurtado 1984, Green 1994, Zárate \& Dutton 2002).

Results from our study will help managers in the GNPS to formulate strategies to protect critical habitats for green turtles. Furthermore, these results are essential for sea turtle demography and population modeling. Hatching and emergence success as key demographic parameters can be used to determine how quickly a population might recover from population perturbations. In addition, these results provide a baseline for studies on climate change and its implications for future impacts.

Acknowledgements. We gratefully acknowledge assistance in the field and research provided by M. Robles, C. Chasiluisa, I. Bravo, S. Castillo, N. Beaumont, E. Cadena, J. Carrión, M. A. Fernie, C. Angulo, F. Gómez, M. Bosquirolli, S. Cahoon, E. Palácios, M. González, J. Solano, D. Páez, C. R. Hasbun, P. Swanell, A. Gaos, I. Yáñez, and L. Martínez, and all of the volunteers in the field. We thank H. Herrera and A. M. Ortega for rearing flies at the Charles Darwin Foundation in Puerto Ayora, Galápagos, and B. Sinclair of the Zoologisches Forschungs Institute und Museum Alexander Koenig in Germany for identifying adult flies. We thank E. M. López from the National Mexican Turtle Center in Oaxaca, Mexico, for his insights on beetle predation. We also thank W. Tapia from the GNPS for support and comments on the manuscript. Fig. 1 was created with seaturtle.org Maptool (www.seaturtle.org/maptool/). Funding was provided by the National Marine Fisheries Service (NMFS, USA), Conservación Internacional (CI, Ecuador), National Fish and Wildlife Foundation (NFWF, USA), Ecology Project Interna- tional (EPI, USA), Swiss Friends of Galápagos, Charles Darwin Foundation Canada, Turner Foundation, GAP Adventures, Laboratorio Epidemiología y Patología Fabricio Valverde (GNP and University of Guayaquil). We also thank the Galápagos National Park for providing research permits for this investigation and the collection of samples. We thank the administration, quarantine and inspection, and science areas and their staff at the Charles Darwin Foundation for their support and assistance.

\section{LITERATURE CITED}

Abella E, Marco A, López-Jurado LF (2007) Success of delayed translocation of loggerhead turtle nests. J Wildl Manag 71:2290-2296

Ackerman RA (1980) Physiology and ecological aspect of change by sea turtle eggs. Am Zool 20:575-583

Allgoewer K (1980) Egg predation on the green sea turtle Chelonia mydas agassizi by the scarabeid beetle Trox suberosus on the Galápagos Islands. Progress Report Files CDRS, Santa Cruz, Galápagos Islands

Bjorndal KA, Bolten AB (1992) Spatial distribution of green turtle (Chelonia mydas) nests at Tortuguero, Costa Rica. Copeia 1992:45-53

Bolten AB (1999) Techniques for measuring sea turtles. In: Eckert KL, Bjorndal KA, Abre-Grobois FA, Donnelly M (eds) Research and management techniques for the conservation of sea turtles. IUCN/SSC Marine Turtle Specialist Group Publ 4:1-5

Brown L, Macdonald DW (1995) Predation on green turtle Chelonia mydas nests by wild canids at Akyatan Beach, Turkey. Biol Conserv 71:55-60

Bustard HR, Tognetti KP (1969) Green sea turtles: a discrete simulation of density-dependent population regulation. Science 163:939-941

Calvopiña JE (1985) Biológica reproductiva y determinación del área de vida (homerange) de los cerdos ferales, Sus scrofa L de la Isla San Salvador, Galápagos. Universidad Técnica de Ambato, Ambato

Caut S, Guirlet E, Jouquet P, Girondot M (2006) Influence of nest location and yolkless eggs on the hatching success of leatherback turtle clutches in French Guiana. Can J Zool 84:908-915

> Chaloupka M (2002) Stochastic simulation modeling of southern Great Barrier Reef green turtle population dynamics. Ecol Modell 148:79-109

Charles Darwin Foundation (2012) CDF climate database. www.darwinfoundation.org (accessed 10 October 2012)

> Coblentz BE, Baber DW (1987) Biology and control of feral pigs on Isla Santiago, Galápagos, Ecuador. J Appl Ecol 24:403-418

Cornelius SE, Alvarado-Ulloa M, Castro JC, Mata del Valle M, Robinson DC (1991) Management of olive ridley sea turtles (Lepidochelys olivacea) nesting at playas Nancite and Ostional, Costa Rica. In: Robinson JR, Redford KH (eds) Neotropical wildlife use and conservation. The University of Chicago Press, Chicago, p 111-135

Cruz F, Donlan CJ, Campbell K, Carrion V (2005) Conservation action in the Galápagos: feral pig (Sus scrofa) eradication from Santiago Island. Biol Conserv 121:473-478

Dutton DL, Dutton PH, Chaloupka M, Boulon RH (2005) Increase of a Caribbean leatherback turtle Dermochelys coriacea nesting population linked to long term nest protection. Biol Conserv 126:186-194 
Foley AM, Peck SA, Harman GR (2006) Effects of sand characteristics and inundation on the hatching success of loggerhead sea turtle (Caretta caretta) clutches on lowrelief mangrove islands in southwest Florida. Chelonian Conserv Biol 5:32-41

Girondot M, Tucker AD, Rivalan P, Godfrey MH, Chevalier J (2002) Density-dependent nest destruction and population fluctuations of Guianan leatherback turtles. Anim Conserv 5:75-84

Green D (1994) Galápagos Sea turtles: an overview. In: Schroeder BA, Witheringhton BS (eds) Proc 13th symposium sea turtle biology and conservation. NOAA Tech Memo NMFS-SEFSC 314:65-68

Green D, Ortiz-Crespo F (1982) Status of sea turtle populations in the central eastern Pacific. In: Bjorndal KA (ed) Biology and conservation of sea turtles. Smithsonian Institution Press, Washington, DC, p 221-233

Güçlü O, Bıyık H, Sahiner A (2010) Mycoflora identified from loggerhead turtle (Caretta caretta) egg shells and nest sand at Fethiye Beach, Turkey. Afr J Microbiol Res 4:408-413

Halffter G, Escobar F, Baena ML, Ríos M, Escobar F (2009) Distribución espacial y evaluación del daño de Omorgus suberosus (Coleoptera:Trogidae) en nidos de la tortuga marina Lepidochelys olivácea. Informe Final, Comisión Nacional de Áreas Naturales Protegidas, Oaxaca

Hayes RH, Marsh NB, Bishop GA (1996) Sea turtle nest depredation by a feral hog; a learned behavior. In: Keinath JA, Barnard DE, Musick JA, Bell BA (eds) Proceedings of the 15th annual symposium on sea turtle biology and conservation. NOAA Tech Memo MNFSSEFSC 387:129-134

Hays GC, Speakman JR (1993) Nest placement by loggerhead turtles, Caretta caretta. Anim Behav 45:47-53

Hirth HF (1980) Some aspects of the nesting behavior and reproductive biology of sea turtles. Am Zool 20:507-523

Hirth HF (1997) Synopsis of the biological data on the green turtle Chelonia mydas (Linnaeus, 1758). Fish and Wildlife Service, US Department of the Interior, Washington, DC

- Hitipeuw C, Dutton PH, Benson S, Thebu J, Bakarbessy J (2007) Population status and internesting movement of leatherback turtles, Dermochelys coriacea, nesting on the northwest coast of Papua, Indonesia. Chelonian Conserv Biol 6:28-36

- Honarvar S, O'Connor MP, Spotila JR (2008) Density-dependent effects on hatching success of the olive ridley turtle, Lepidochelys olivacea. Oecologia 157:221-230

Hurtado M (1984) Registro de la anidación de la tortuga negra, Chelonia mydas en las islas Galápagos. Bol Cient Tec Inst Nac Pesca Ecuad 4:77-106

IUCN (2012) IUCN Red List of Threatened Species, Version 20122. www.iucnredlist.org (accessed 28 October 2012)

Katselidis KA, Schofield G, Stamou G, Dimopoulos P, Pantis JD (2012) Females first? Past, present and future variability in offspring sex ratio at a temperate sea turtle breeding area. Anim Conserv 15:508-518

Kudo H, Murakami A, Watanabe S (2003) Effects of sand hardness and human beach use on emergence success of loggerhead sea turtles on Yakushima Island, Japan. Chelonian Conserv Biol 4:695-696

Leighton PA, Horrocks JA, Kramer DL (2009) How depth alters detection and capture of buried prey: exploitation of sea turtle eggs by mongooses. Behav Ecol 20: 1299-1306
Limpus CJ, Miller J, Parmenter C, Limpus D (2003) The green turtle, Chelonia mydas, population of Raine Island and the northern Great Barrier Reef 1843-2001. Mem Queensl Mus 49:349-440

López EM, Antemate A, Beltran FJ, Olivera A (1994) Control del escarabajo del genero Trox que provoca la destrucción de los huevos en incubación de las tortugas golfinas Lepidochelys olivacea en la playa La Escobilla, Tonameca, Pochuta, Oaxaca. Informe del Programa de Investigación y Conservación de las tortugas Marinas, Escuela de Medicina Veterinaria y Zootecnia, Universidad Autónoma 'Benito Juarez' de Oaxaca, Oaxaca

> Marcovaldi AM, Chaloupka M (2007) Conservation status of the loggerhead sea turtle in Brazil: an encouraging outlook. Endang Species Res 3:133-144

Matsuzawa Y, Sato K, Sakamoto W, Bjorndal KA (2002) Seasonal fluctuations in sand temperature: effects on the incubation period and mortality of loggerhead sea turtle (Caretta caretta) pre-emergent hatchlings in Minabe Japan. Mar Biol 140:639-646

Mazaris DA, Breckling B, Matsinos GY (2006) An individualbased model of a sea turtle population to analyze effects of age dependent mortality. Ecol Modell 198:174-182

Miller JD (1999) Determining clutch size and hatch success. In: Eckert KL, Bjorndal KA, Abreu-Grobois FA, Donnelly $M$ (eds) Research and management techniques for the conservation of sea turtle. IUCN/SSC Marine Turtle Specialist Group Publ 4:124-129

Mortimer JA (1982) Factors influencing beach selection by nesting sea turtles. In: Bjorndal KA (ed) Biology and conservation of sea turtles. Smithsonian Institution Press, Washington, DC, p 45-51

> Mortimer JA (1990) The influence of beach sand characteristics on the nesting behavior and clutch survival of green turtles (Chelonia mydas). Copeia 1990:802-817

Mrosovsky N, Yntema CL (1980) Temperature dependence of sexual differentiation in sea turtles: implications for conservation practices. Biol Conserv 18:271-280

National Research Council (2010) Decline of the sea turtles: causes and prevention. National Academies Press, Washington, DC

Ocana MAS (2011) Arribada nesting of olive ridley sea turtles (Lepidochelys olivacea) at La Escobilla, Mexico. MSc thesis, Oregon State University, Corvallis, OR

Peters A, Verhoeven KJF, Strijbosch H (1994) Hatching and emergence in the Turkish Mediterranean loggerhead turtle, Caretta caretta: a natural cause for egg and hatchling failure. Herpetologica 50:369-373

Phillott AD, Parmenter CJ (2001) The distribution of failed eggs and the appearance of fungi in artificial nests of green (Chelonia mydas) and loggerhead (Caretta caretta) sea turtles. J Zool (Lond) 49:773-718

Plan de Manejo de Conservación y Uso Sustentable para la Reserva Marina de Galápagos (1999) Publicado en el Registro Oficial No. 173, el 20 de abril de 1999. Registro official, Quito

Plan de Manejo del Parque Nacional Galápagos (2005) Edición Especial No. 1 Registro Oficial del 30 de diciembre del 2005. Registro official, Quito

Segura LN, Cajade R (2010) The effects of sand temperature on pre-emergent green sea turtle hatchlings. Herp Conserv Biol 5:196-206

Seminoff JA (2004) MSTG global assessment of green turtles (Chelonia mydas) for the IUCN Red List. IUCN Species Survival Commission, April 2004. www.iucn-mtsg.org/ 
red_list/cm/MTSG_Chelonia_mydas_Assessment_April2004.pdf (accessed 10 October 2012)

Seminoff JA (2007) Green sea turtle (Chelonia mydas) 5year review: summary and evaluation. National Marine Fisheries Service Office of Protected Resources, Silver Spring, MD, and US Fish and Wildlife Service Southeast Region Jacksonville Ecological Services Field Office Jacksonville, FL

Stancyk SE (1982) Non-human predators of sea turtles and their control. In: Bjorndal KA (ed) Biology and conservation of sea turtles. Smithsonian Institution Press, Washington, DC, p 139-152

Starbird C, Suarez M (1994) Leatherback sea turtle nesting on the north Vogelkop coast of Irian Jaya and the discovery of a leatherback sea turtle fishery on Kai Kecil Island. In: Bjorndal KA, Bolten AB, Johnson DA, Eliazar PJ (eds) Proceedings of the 14th annual symposium on sea turtle biology and conservation. NOAA Tech Memo NMFSSEFSC 351:143-146

Tapilatu RF, Tiwari M (2007) Leatherback turtle, Dermochelys coriacea, hatching success at Jamursba-Medi and Wermon Beaches in Papua, Indonesia. Chelonian Conserv Biol 6:154-158

Tiwari M, Bjorndal KA, Bolten AB, Bolker BM (2006) Evaluation of density-dependent processes and green turtle Chelonia mydas hatchling production at Tortuguero, Costa Rica. Mar Ecol Prog Ser 326:283-293

Editorial responsibility: Graeme Hays, Swansea, UK
Turkozan O, Yamamoto K, Yilmaz C (2011) Nest site preference and hatching success of green (Chelonia mydas) and loggerhead (Caretta caretta) sea turtles at Akyatan Beach, Turkey. Chelonian Conserv Biol 10:270-275

> Van Buskirk J, Crowder LB (1994) Life-history variation in marine turtles. Copeia 1994:66-81

> Whitmore CP, Dutton PH (1985) Infertility, embryonic mortality, and nest-site selection in leatherback and green sea turtles in Suriname. Biol Conserv 34:251-272

> Witt MJ, Hawkes LA, Godfrey MH, Godley BJ, Broderick AC (2010) Predicting the impacts of climate change on a globally distributed species the case of the loggerhead turtle. J Exp Biol 213:901-911

Wyneken J, Burke TJ, Salmon M, Pedersen DK (1988) Egg failure in natural and relocated sea turtle nests. J Herpetol 22:88-96

Zárate P (2003) Evaluación del impacto de los planes de erradicación de los chanchos salvajes sobre la recuperación de los nidos de tortuga verde Chelonia mydas en playa Espumilla, Isla Santiago, Islas Galápagos. Informe resumen presentado a Conservación Internacional (CI), Santa Cruz, Galápagos Islands

Zárate P, Dutton PH (2002) Tortuga verde. In: Danulat E, Edgar GJ (eds) Reserva Marina de Galápagos Línea base de la biodiversidad. Fundación Charles Darwin/Servicio Parque Nacional Galápagos, Santa Cruz, Galápagos, p 305-323

Submitted: March 1, 2013; Accepted: August 14, 2013

Proofs received from author(s): October 10, 2013 